Nevada

Environmental

Restoration

Project

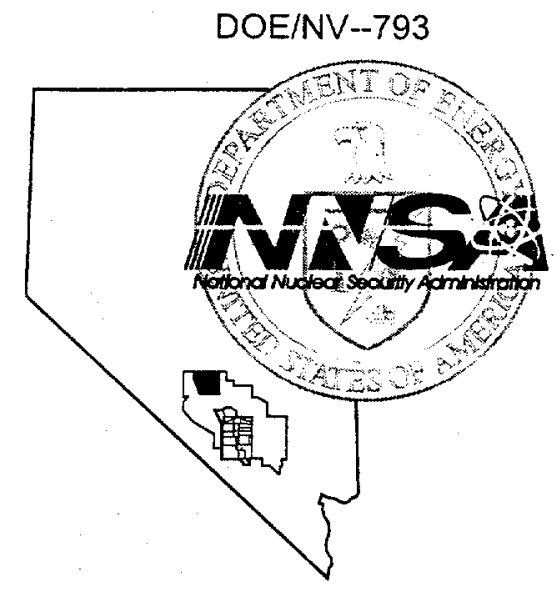

Post-Closure Inspection Report for Corrective Action Unit 407:

Roller Coaster RadSafe Area

Tonopah Test Range, Nevada

Calendar Year 2001

Controlled Copy No.:

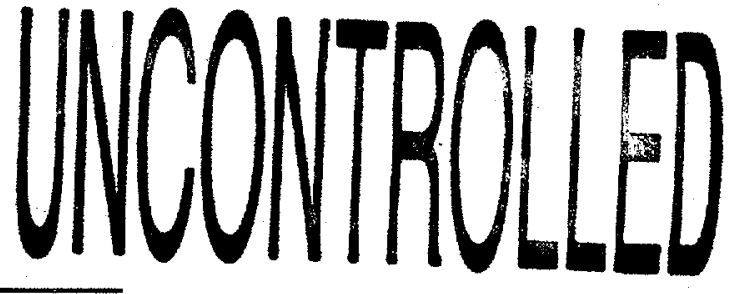

Revision: 0

January 2002

Environmental Restoration

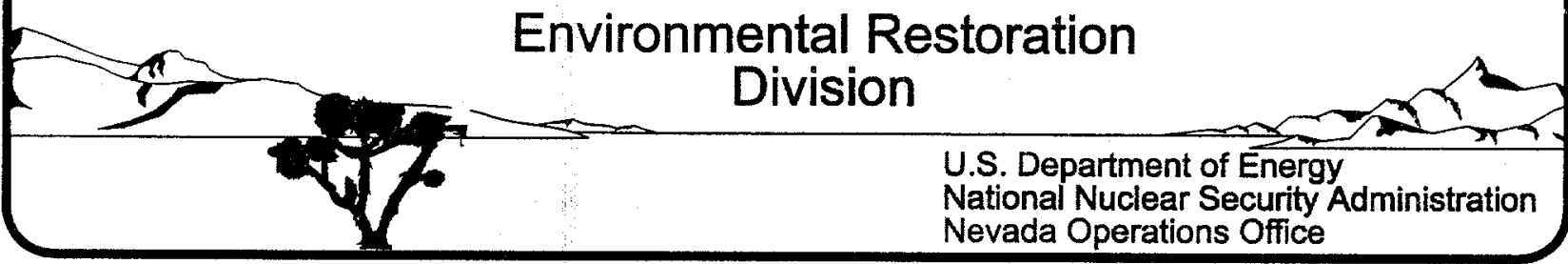




\section{DISCLAIMER STATEMENT}

Reference herein to any specific commercial product, process, or service by trade name, trademark, manufacturer, or otherwise, does not necessarily constitute or imply its endorsement, recommendation, or favoring by the U.S. Government or any agency thereof or its contractors or subcontractors.

\section{AVAILABILITY STATEMENT}

Available for sale to the public from-

U.S. Department of Commerce

National Technical Information Service

5285 Port Royal Road

Springfield, VA 22161-0002

Telephone: 800.553 .6847

Fax: 703.605.6900

E-mail: orders@ntis.fedworld.gov

Online ordering: http://www.ntis.gov/ordering.htm

Available electronically at http://www.doe.gov/bridge

Available for a processing fee to U.S. Department of Energy and its contractors, in paper, fromU.S. Department of Energy

Office of Scientific and Technical Information

P.O. Box 62

Oak Ridge, TN 37831-0062

Telephone: 865.576 .8401

Fax: 865.576.5728

E-mail: reports@adonis.osti.gov 


\title{
POST-CLOSURE INSPECTION REPORT FOR CORRECTIVE ACTION UNIT 407: ROLLER COASTER RADSAFE AREA TONOPAH TEST RANGE, NEVADA CALENDAR YEAR 2001
}

\author{
Prepared for \\ U. S. Department of Energy \\ National Nuclear Security Administration \\ Nevada Operations Office \\ Work Performed Under Contract No. \\ DE-AC08-96NV11718
}

Controlled Copy No.:

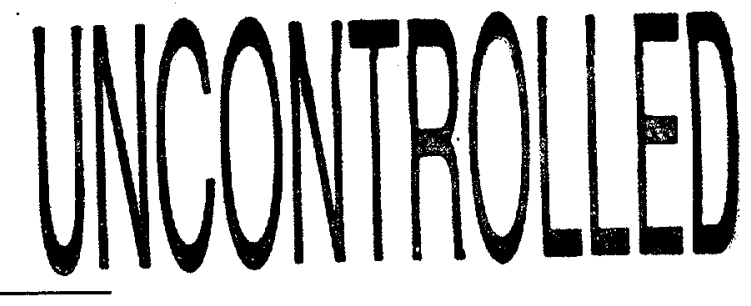

Revision: 0

January 2002 

DOE/NV-793

\section{POST-CLOSURE INSPECTION REPORT FOR CORRECTIVE ACTION UNIT 407: ROLLER COASTER RADSAFE AREA TONOPAH TEST RANGE, NEVADA CALENDAR YEAR 2001}

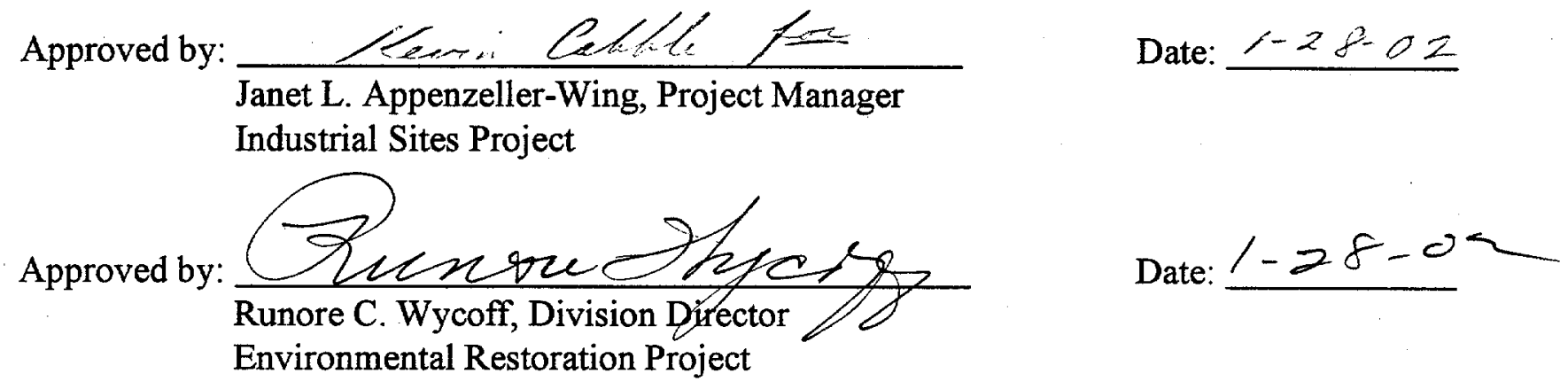




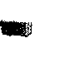

$=$

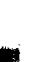




\section{TABLE OF CONTENTS}

1.0 INTRODUCTION $\ldots \ldots \ldots \ldots \ldots \ldots \ldots \ldots \ldots \ldots \ldots \ldots \ldots \ldots \ldots \ldots \ldots \ldots \ldots \ldots$

2.0 INSPECTION RESULTS $\ldots \ldots \ldots \ldots \ldots \ldots \ldots \ldots \ldots \ldots \ldots \ldots \ldots \ldots \ldots \ldots$

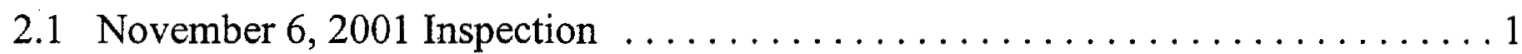

3.0 CONCLUSIONS AND RECOMMENDATIONS $\ldots \ldots \ldots \ldots \ldots \ldots \ldots \ldots \ldots \ldots$

\section{FIGURES}

FIGURE 1 - ROLLER COASTER RADSAFE CAU 407 LOCATION MAP ........... 2

\section{ATTACHMENTS}

ATTACHMENT A - INSPECTION CHECKLISTS

ATTACHMENT B - FIELD NOTES

ATTACHMENT C - PHOTOGRAPH LOG AND PHOTOGRAPHS

ATTACHMENT D - NDEP ENVIRONMENTAL RESTORATION PROJECT DOCUMENT REVIEW SHEET

DISTRIBUTION LIST 
Post-Closure Inspection Report

CAU No. 407

Roller Coaster RadSafe Area

Revision: 0

Date: January 23, 2002

THIS PAGE INTENTIONALLY LEFT BLANK 


\subsection{INTRODUCTION}

Post-closure monitoring requirements for the Roller Coaster RadSafe Area (Corrective Action Unit [CAU] 407) (Figure 1) are described in Closure Report for Corrective Action Unit 407. Roller Coaster RadSafe Area, Tonopah Test Range, Nevada, report number DOE/NV-694, October 2001. The Closure Report (CR) was submitted to the Nevada Division of Environmental Protection (NDEP) on April 24, 2001. No issues with the post-closure monitoring plan, Section 5.0, were raised. However, other concerns raised by stakeholders required that the $\mathrm{CR}$ be revised. Revision 1 of CR was issued in December of 2001 and was approved by NDEP on January 7, 2002. Section 5.2 of the NDEP-approved CR calls for site inspections to be conducted within the first six months following completion of cover construction. Following the first six months, site inspection are to be conducted twice yearly for the next two years. This report provides the results of the six month post-construction site inpsection.

As stated in Section 5.2 of the CR, Post-closure site inspections at CAU 407 consists of the following:

- Visual site inspections done twice a year to evaluate the condition of the cover and plant development.

- Verification that the site is secure and condition of the fence and posted warning signs.

- Notice of any subsidence, erosion, unauthorized excavation, etc., deficiencies that may compromise the integrity of the unit.

- $\quad$ Remedy of any deficiencies within 90 days of discovery.

- $\quad$ Preparation and submittal of an annual report.

To meet the fiscal year 2002 post-closure inspection schedule, the first post-closure site inspection was conducted on November 6,2001. The site inspection was conducted after completion of the revegetation activities (October 24, 2000) and submittal of revision 0 of the $\mathrm{CR}$ (October 31, 2001). All site inspections were conducted in accordance with the Post-Closure Inspection requirements stated in revision 0 of the $C R$.

This report includes copies of inspection checklist, photographs, recommendations, and conclusions. The Post-Closure Inspection Checklist is found in Attachment A, a copy of the field notes is found in Attachment B, and copies of the inspection photographs are found in Attachment C.

\subsection{INSPECTION RESULTS}

\subsection{November 6, 2001 Inspection}

The first biannual post-closure inspection of CAU 407 was completed on November 6, 2001. Numerous small mammal burrows were observed along cover side slopes and in the area inside 

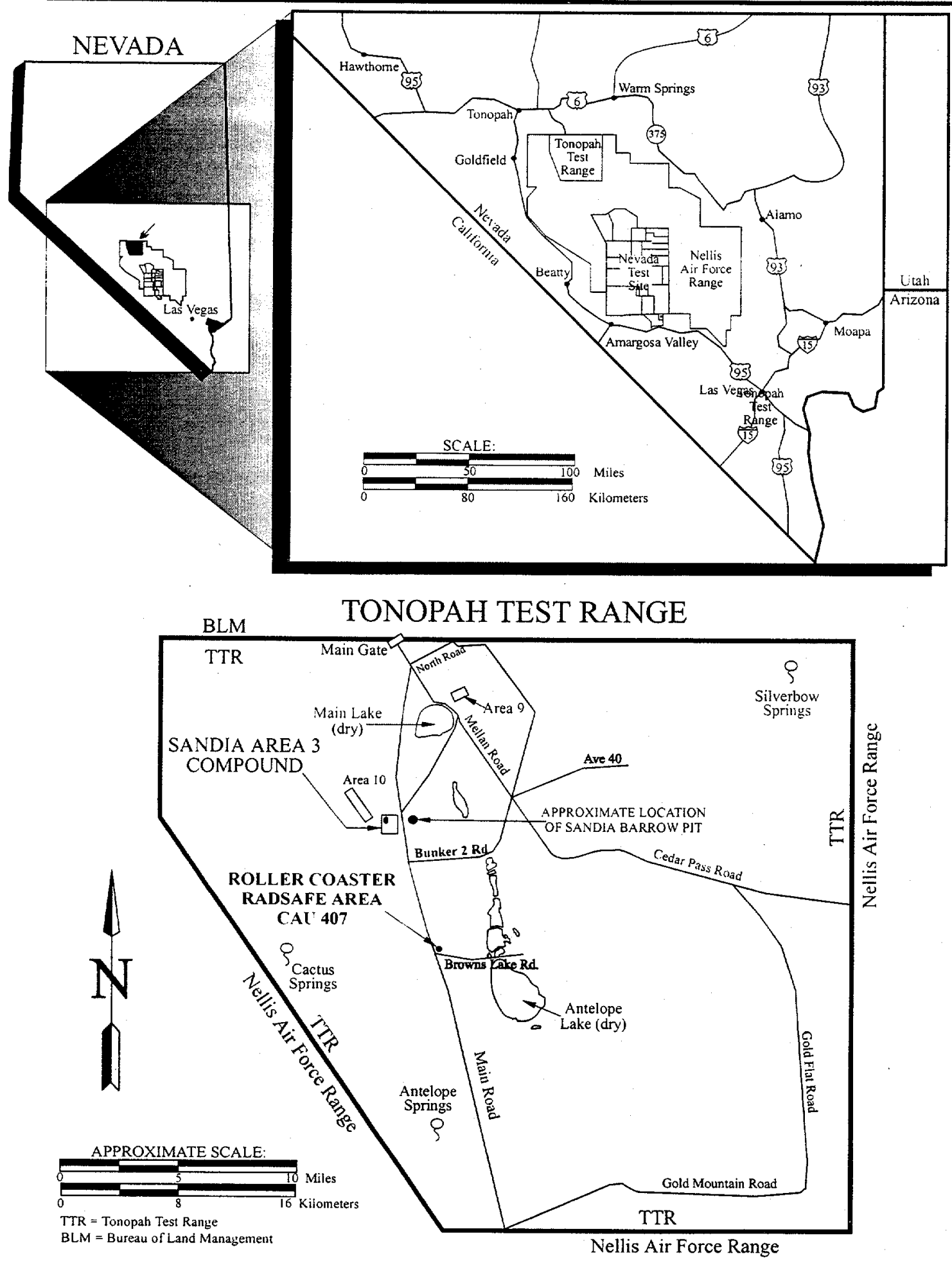

FIGURE 1

ROLLER COASTER RADSAFE AREA CAU 407 LOCATION MAP 
the fence. The fence is a three strand barbed wire fence; no chicken wire mesh is present to prevent small mammals from entering the fenced area. The average burrow measured approximately 5 centimeters ( 2 inches) in diameter and extended to an observed depth of approximately 0.3 meters ( 1 foot). The burrows did not effect the integrity of the cover. The fence was in good repair with no apparent holes or breaches in the fencing. The signs warning of the presence of underground radioactive material posted on tee posts are in good condition. No erosion, subsidence, or cracking of the cover surface was observed. The vegetation inside the fence and on the cover appeared to be healthy and well established. Overall, the cover, fencing, warning signs, and the area inside the fence were observed to be stable and in good condition. No further maintenance or repairs were recommended.

\subsection{CONCLUSIONS AND RECOMMENDATIONS}

Numerous small mammal burrows are present along the toe of the cover but do not appear to effect the integrity of the cover. Small mammal have burrowed under the fence at several locations: these burrows were backfilled using a shovel. There is no evidence of drainage or erosion through the site. The condition of the is good, with a healthy cover of plant species growing on the cover and within the fenced area. Overall, the area fencing and posted warning signs are in excellent condition. Some portions of the cover are mounded or uneven and cover maintenance work is scheduled for mid 2002. Maintenance work will include grading and contouring portions of the existing cover. No other modifications or repairs to the cover, or changes in the frequency of site inspections, are recommended at this time. 
Post-Closure Inspection Report CAU No. 407

Roller Coaster RadSafe Area

Revision: 0

Date: January 23, 2002

\section{THIS PAGE INTENTIONALLY LEFT BLANK}


Post-Closure Inspection Report

CAU No. 407

Roller Coaster RadSafe Area

Revision: 0

Date: January 23, 2002

\section{ATTACHMENT A}

\section{INSPECTION CHECKLISTS}


Post-Closure Inspection Report CAU No. 407

Roller Coaster RadSafe Area

Revision: 0

Date: January 23, 2002 


\begin{tabular}{|c|c|}
\hline Date of Last inspection: N/A First Site Inspection & Reason for Last Inspection: $N / A$ \\
\hline Responsible Agency: $N \sim 5 A / N \mathcal{B N}-Z \mathbb{R}$ & Project Manager: We yne Johnson \\
\hline \multicolumn{2}{|l|}{ Inspection Date: 6 Novem ber 2001} \\
\hline Inspector (name, title, organization): Kesun $B_{1} C_{a}$ & II TH Technical Lead BNER \\
\hline
\end{tabular}

\section{A. GENERAL INSTRUCTIONS}

1. All checklist items must be completed and detailed comments made to document the results of the site inspection. The completed checklist is part of the field record of the inspection. Additional pages should be used as necessary to ensure that a complete record is made. Attach the additional pages and number all pages upon completion of the inspection.

2. Any checklist line item marked by an inspector in a SHADED BOX, must be fully explained or an appropriate reference to previous reports provided. The purpose of this requirement is to provide a written explanation of inspector observations and the inspector's rationale for conclusions and recommendations. Explanations are to be placed on additional attachments and cross-referenced appropriately. Explanations, in addition to narrative, will take the form of sketches, measirements, annotated site maps.

3. The site inspection is a walking inspection of the entire site including the perimeter and sufficient transects to be able to inspect the entire surface and all features specifically described in this checklist.

4. A standard set of color $35 \mathrm{~mm}$ photographs is required. In addition, all anomalous features or new features (such as changes in adjacent area land use) are to be photographed. A photo log entry will be made for each photograph taken.

5. This unit will be inspected biannually with formal reporting to the Nevada Division of Environmental Protection to be done annually. The annual report will include an executive summary, this inspection checklist with field notes and photo log attached, and recommendations and conclusions.

\begin{tabular}{||l|c|c|l||}
\hline \hline B. PREPARATION (TO be completed prior to site visit) & YES & NO & EXPLANATION \\
\hline 1. Site as-built plans and site base map reviewed. & & & \\
\hline 2. Previous inspection reports reviewed. \\
$\begin{array}{l}\text { a. Were anomalies or trends detected on previous } \\
\text { inspections? } \\
\text { b. Was maintenance performed? }\end{array}$ & & & This is first jite mspection \\
\hline $\begin{array}{l}\text { 3. Site maintenance and repair records reviewed. } \\
\text { a. Has site repair resulted in a change from as-built } \\
\text { conditions? } \\
\text { b. Are revised as-builts available that reflect repair changes? }\end{array}$ & & N/A & \\
\hline \hline C. SITE INSPECTION (TO be completed during inspection) & YES & NO & EXPLANATION \\
\hline
\end{tabular}

1. Adjacent off-site features within watershed areas.

a. Have there been any changes in use of adjacent area?

b. Are there any new roads or trails?

c. Has there been a change in the position of nearby washes?

d. Has there been lateral excursion or erosion/deposition of nearby washes?

e. Are there new drainage channels?

f. Change in surrounding vegetation?

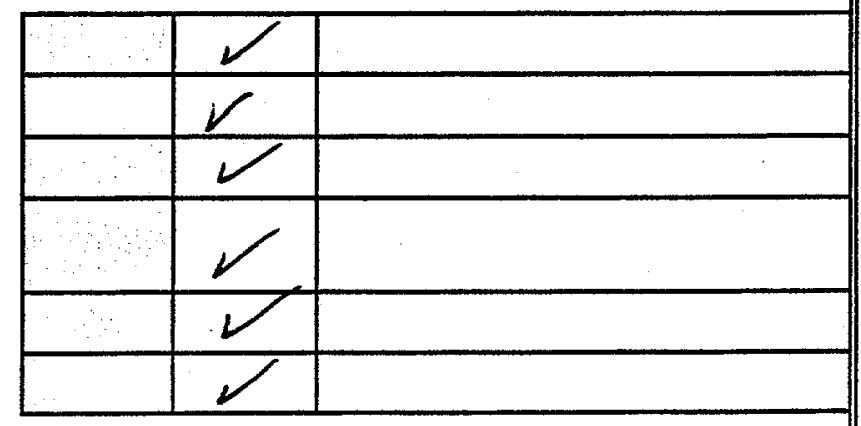

2. Security fence, signs.

a. Displacement of fences, site markers, boundary markers, or monuments?

b. Have any signs been damaged or removed? (Number of signs replaced: Q

c. Were gates locked?

\begin{tabular}{|l|l|l|}
\hline & \multicolumn{1}{|l|}{} \\
\hline & \multicolumn{1}{|c|}{} & \\
\hline & $\nu$ & NA no gate present \\
\hline
\end{tabular}




\section{CAU 407: ROLLER COASTER RADSAFE AREA, POST-CLOSURE MONITORING CHECKLIST}

3. Waste Unit cover.

a. Is there evidence of settling?

b. Is there cracking?

c. Is there evidence of erosion around the cap (wind or water)?

d. Is there evidence of animal burrowing?

e. Do natural processes threaten to integrity of any cover or site marker?

f. Other?

\begin{tabular}{|c|c|c|}
\hline YES & No & EXPLANATION \\
\hline & $V$ & \\
\hline & $V$ & \\
\hline & & \\
\hline$\sqrt{7}$ & & $\begin{array}{l}\text { numerous small mamal burmo } \\
\text { phesemt }\end{array}$ \\
\hline & $\checkmark$ & . \\
\hline & $\forall$ & \\
\hline
\end{tabular}

4. Vegetative cover

a. Is perimeter fence or mesh fencing damaged?

b. Is there evidence of horses or rabbits on site?

c. Is organic mulch adequate to prevent erosion?

d. Are weedy annual plants present? If yes, are they a problem?

e. Are seeded plant species found on site?

f. Is there evidence of plant mortality?

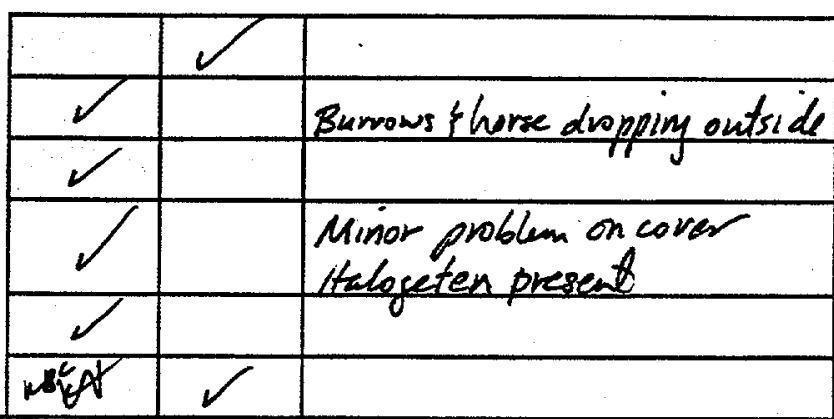

5. Photo Documentation

a. Has a photo log been prepared?

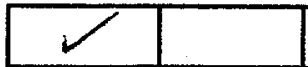

c. Number of photos exposed ( 7

\section{FIELD CONCLUSIONS}

1. Is there an imminent hazard to the integrity of the unit? (Immediate report required)

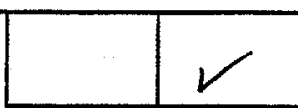

Person/Agency to whom report made

2. Are more frequent inspections required?

3. Are existing maintenance/repair actions satisfactory?

4. Is other maintenance/repair necessary?

5. Is current status/condition of vegetative cover satisfactory?

6. Rationale for field conclusions: Area in good condetion. Fence and warniy sigus in' good caxdedion No bunny fencing present. Nuraevous small mamal burous prepeat but they donot apear to eflect the internty of the cover teathy vejetation insich fence.

\section{E. CERTIFICATION}

I have conducted an inspection of the Roller Coaster Sewage Lagoons \& North Disposal Trench, CAU 404, at the TTR in accordance with the Post-Closure Monitoring Plan (see Closure Report) as recorded on this checklist, attached sheets, field notes, photo logs, and photographs.

Chief Inspector's Signature: Len-6. Qumpell

Title: BNER Technichl Lead

Printed Name: Kevin B. Camplell

Date: 06 Novembor 2001 
Post-Closure Inspection Report

CAU No. 407

Roller Coaster RadSafe Area

Revision: 0

Date: January 23, 2002

ATTACHMENT B

FIELD NOTES 
Post-Closure Inspection Report CAU No. 407

Roller Coaster RadSafe Area

Revision: 0

Date: January 23. 2002

THIS PAGE INTENTIONALLY LEFT BLANK 
22 TITLE

PROJECT NO.

Work continued from Page 21

BOOK NO.

Roller Coaster Sewage Lyon (CAu404)

- 1223 Amir on sit.

bates, feme, signs all in excellent condition.

Cover vegetation heathy and more dense than ont side fence.

5 Small burrow's present at base of fence line, bach filled by band.

Numerous small mural barrows present inside fence burry fencing

is not buried as at other sites allowing animals access under fencing Ne burrows present on top of tossed as a.

No evidence of erosion of cover side slope

- Drainage swill north of cover in excellent condition - no exponent erosion Reaticched two signs with hog rings

1300 Depart site

1310 Rollercoaster Rad Sate site (cantor)

5 Barbed wire fencing in good condition. No bunny fencing present. Postings "Underground Radioactive Maternal" still up/ in place Vegetation inside fence very healthy.

Numerous small mamas burrows present inside fenced area and on side slopes of cover.

- No the to integinty of cover

All signs in good shape

1326 Depart site

1335 A3-4 site (CAU 423)

All 5 above-grade monument o in good condition

All attached signs in good condition

Vegetation mainly hologeten some native species all head thy but sparse.

Many small mama burrows present.

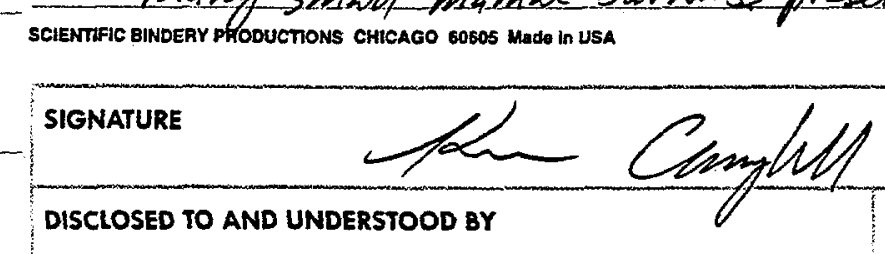

Work continued to Page 23

DISCLOSED TO AND UNDERSTOOD BY

DATE

WITNESS

DATE $1 / / 6 l 01$

DATE 
Post-Closure Inspection Report

CAU No. 407

Roller Coaster RadSafe Area

Revision: 0

Date: January 23, 2002

ATTACHMENT C

\section{PHOTOGRAPH LOG AND PHOTOGRAPHS}


Post-Closure Inspection Report

CAU No. 407

Roller Coaster RadSafe Area

Revision: 0

Date: January 23,2002

THIS PAGE INTENTIONALLY LEFT BLANK 


\section{PHOTOGRAPH LOG}

\begin{tabular}{|c|c|l||}
\hline $\begin{array}{c}\text { PHOTO } \\
\text { NUMBER }\end{array}$ & DATE & \multicolumn{1}{c||}{ DESCRIPTION } \\
\hline \hline 1 & $11 / 06 / 2001$ & View looking east from outside fence at site. \\
\hline 2 & $11 / 06 / 2001$ & $\begin{array}{l}\text { View looking northeast from outside the fence. Note the } \\
\text { presence of sparse healthy native grass and shrub species on and } \\
\text { about cover. }\end{array}$ \\
\hline 3 & $11 / 06 / 2001$ & Small mammal burrow holes inside fence line. \\
\hline 4 & $11 / 06 / 2001$ & View to southeast of cover from outside fence. \\
\hline
\end{tabular}


Post-Closure Inspection Report

CAU No. 407

Roller'Coaster RadSafe Area

Revision: 0

Date: January 23, 2002

THIS PAGE INTENTIONALLY LEFT BLANK 
Post-Closure Inspection Report CAU No. 407

Roller Coaster RadSafe Area

Revision: 0

Date: January 23, 2002

ATTACHMENT D

\section{NDEP ENVIRONMENTAL RESTORATION PROJECT DOCUMENT REVIEW SHEET}


Post-Closure Inspection Report CAU No. 407

Roller Coaster RadSafe Area

Revision: 0

Date: January 23, 2002 


\section{NEVADA ENVIRONMENTAL RESTORATION PROJECT DOCUMENT REVIEW SHEET}

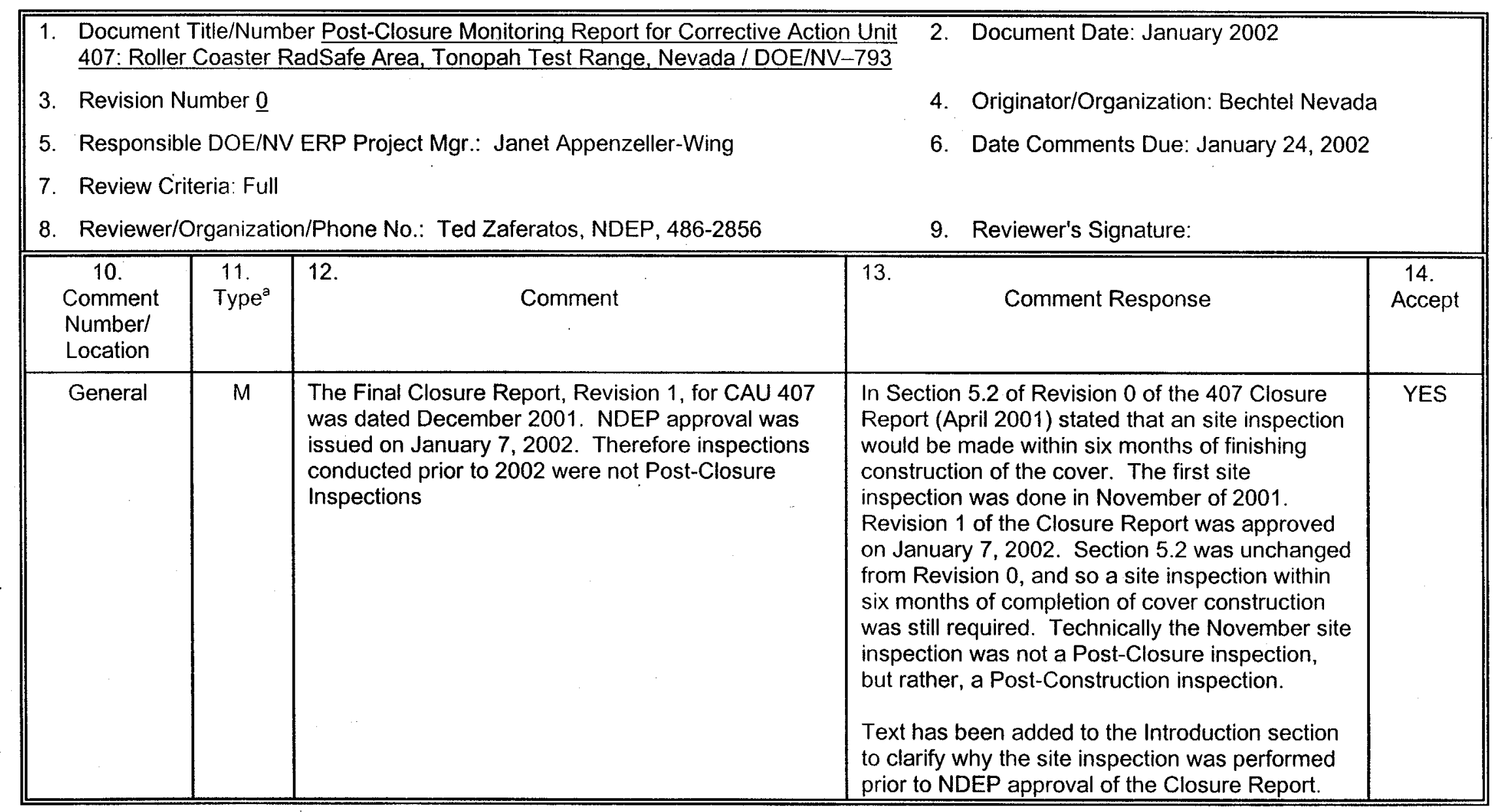

${ }^{a}$ Comment Types: $M=$ Mandatory, $S=$ Suggested. 
Post-Closure Inspection Report CAU No. 407

Roller Coaster RadSafe Area

Revision: 0

Date: January 23, 2002

THIS PAGE INTENTIONALLY LEFT BLANK 


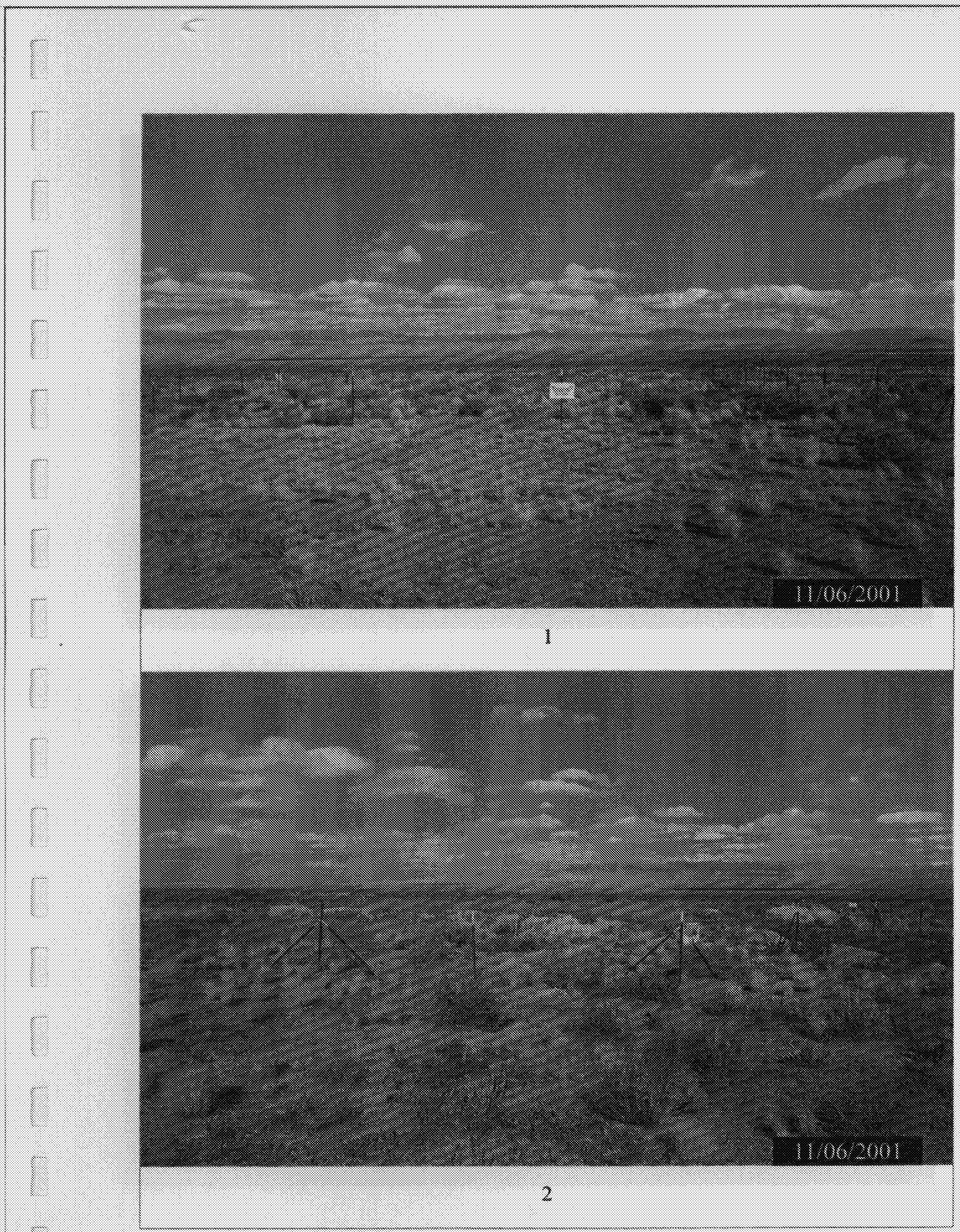




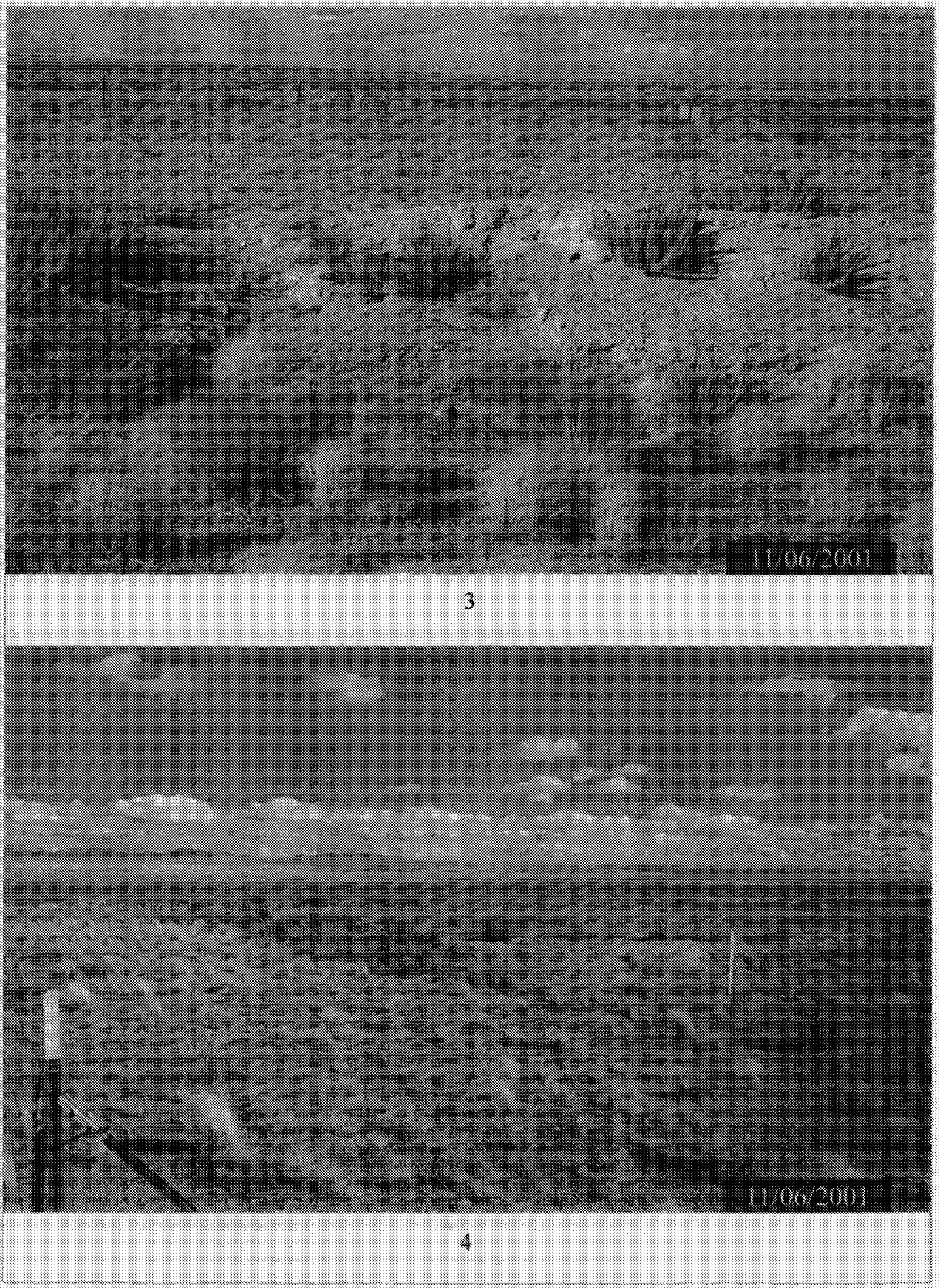


CAU No. 407

Roller Coaster RadSafe Area

Revision: 0

Date: January 23, 2002

\section{DISTRIBUTION LIST}


Post-Closure Inspection Report CAU No. 407

Roller Coaster RadSafe Area

Revision: 0

Date: January 23,2002

THIS PAGE INTENTIONALLY LEFT BLANK 


\section{DISTRIBUTION LIST}

*Provide copy of initial distribution of Revision 0; remainder of list gets Revision 0 if approved without changes. The entire list receives Revision 1, if issued.

\section{Nevada Department of Environmental Protection}

Paul Liebendorfer

Bureau of Federal Facilities

Division of Environmental Protection

333 W. Nye Lane, Room 138

Carson City, NV 89706-0866

Supervisor, Las Vegas Office

1 (Controlled)*

Bureau of Federal Facilities

Division of Environmental Protection

555 E. Washington, Suite 4300

Las Vegas, NV 89010-1043

\section{U.S. Department of Energy}

Janet Appenzeller-Wing

1 (Uncontrolled)*

Project Manager

Environmental Restoration Division

U.S. Department of Energy

National Nuclear Security Administration

Nevada Operations Office

P.O. Box $98518 \mathrm{M} / \mathrm{S} 505$

Las Vegas, NV 89193-8518

Kevin Cabble

1 (Uncontrolled)*

Environmental Restoration Division

U.S. Department of Energy

National Nuclear Security Administration

Nevada Operations Office

P.O. Box $98518 \mathrm{M} / \mathrm{S} 505$

Las Vegas, NV 89193-8518 


\section{DISTRIBUTION LIST (Continued)}

\section{U.S. Department of Energy (continued)}

Sabrina Lawrence

Environmental Restoration Division

U.S. Department of Energy

National Nuclear Security Administration

Nevada Operations Office

P.O. Box $98518 \mathrm{M} / \mathrm{S} 505$

Las Vegas, NV 89193-8518

U.S. Department of Energy

Office of Scientific and Technical Information

1 (electronic copy)

P.O. Box 62

Oak Ridge, TN 37831-0062

U.S. Department of Energy

National Nuclear Security Administration

1 (Controlled) \&

Nevada Operations Office

1 (Uncontrolled)

Public Reading Facility

P.O. Box $98521 \mathrm{M} / \mathrm{S}$ NLV040

Las Vegas, NV 89193-8521

U.S. Department of Energy

National Nuclear Security Administration

1 (Uncontrolled)

Nevada Operations Office

Technical Information Resource Center

P.O. Box $98521 \mathrm{M} / \mathrm{S} 505$

Las Vegas, NV 89193-8521

\section{Bechtel Nevada}

Correspondence Control

1 (Uncontrolled)*

\section{Bechtel Nevada}

P.O. Box $98521 \mathrm{M} / \mathrm{S}$ NLV008

Las Vegas, NV 89193-8521 
Post-Closure Inspection Report

\section{DISTRIBUTION LIST (Continued)}

\section{Bechtel Nevada (continued)}

Environmental Management Library

1 (Uncontrolled)*

Bechtel Nevada

P.O. Box 98521 N/S NLV080

Las Vegas, NV 89193-8521

Kevin Campbell

1 (Uncontrolled)*

Bechtel Nevada

P.O. Box $98521 \mathrm{M} / \mathrm{S}$ NTS306

Las Vegas, NV 89193-8521

Ann Heidema

1 (Uncontrolled)

Bechtel Nevada

P.O. Box $98521 \mathrm{M} / \mathrm{S}$ NLV022

Las Vegas, NV 89193-8521

Ronald Jackson

1 (Uncontrolled)*

Bechtel Nevada

P.O. Box 98521 M/S NTS306

Las Vegas, NV 89193-8521

Wayne Johnson

1 (Uncontrolled)*

Bechtel Nevada

P.O. Box $98521 \mathrm{M} / \mathrm{S}$ NTS306

Las Vegas, NV 89193-8521

Steve Nacht

1 (Uncontrolled)* $^{*}$

Bechtel Nevada

P.O. Box $98521 \mathrm{M} / \mathrm{S}$ NTS306

Las Vegas, NV 89193-8521 


\section{DISTRIBUTION LIST (Continued)}

\section{IT Corporation}

Lynn Kidman

1 (Uncontrolled)*

IT Corporation

P.O. Box 93838 M/S 439

Las Vegas, NV 89193-8521

Garry Romano

1 (Controlled)

IT FFACO Support Office

IT Corporation

P.O. Box 93838 M/S 439

Las Vegas, NV 89193-8521

\section{State Of Nevada}

Manager, Northern Nevada

1 (Controlled) \&

FFACO Public Reading Facility

1 (Uncontrolled)

Nevada State Library and Archives Federal Publications

100 North Stewart Street

Carson City, NV 89701-4285 